\title{
Fructans and Mineral Nutrition
}

\author{
Noureddine Benkeblia*
}

\section{Department of Life Sciences, The Biotechnology Centre, The University of West Indies, Mona Camus, Kingston 7, Jamaica}

\begin{abstract}
Fructan molecules have a history of more than 150 years and ancient peoples used fructans containing plants as food, feed or medicine. The modern history of fructans began with their discovery by Rose (1804) and known at the turn of the $20^{\text {th }}$ century considerable development with Edelman's proposal concerning their metabolism in higher plant. At present time, fructans are considered food not food ingredients, and are found in more than 500 food products resulting in significant daily consumption. Because the science of nutrition itself has changed, fructans are now considered as functional foods and the passionate history of their health benefits continues to arise interest of scientists. Contrary to the fact that non-digestible carbohydrates have been accused of causing an impairment in the small intestine absorption of minerals, research conducted during the last three decades demonstrated that fructans enhanced mineral absorption, and the scientific evidence claiming that fructans enhance mineral absorption is based on both animal and human experiments which are very conclusive. Although different hypotheses have been proposed to explain the roles of fructans in enhancing minerals absorption, the mechanisms behind this enhancement are still unclear, even though investigation have demonstrated that different fructans-related mechanisms may be involved in the increased absorption of minerals due to fructans intake. This review paper aims to report on the recent development and the roles of fructans in enhancing mineral absorption and their deficiencies prevention.
\end{abstract}

Keywords: Fructans, minerals, absorption, deficiency, nutrition.

\section{HISTORY OF FRUCTANS}

Fructan molecules have a history of more than 150 years, and some review articles have reported some historical aspects including little on the general history on fructans research [1-3]. First and prior to the contemporary science of fructans, ancient peoples used fructans containing plants as food, feed or medicine. The modern history of fructans began with their discovery by Rose (1804) and known at the turn of the past century considerable development with Edelman's proposal concerning their metabolism in higher plant. More recently, Fructans research has known a considerable progress, especially with the molecular biology tools, thus the scope of fructans research has expended from basic to applied science. At present time, fructans are considered food and not food ingredients, and are found in more than 500 food products resulting in significant daily consumption. Because the science of nutrition itself has changed, fructans are now considered as functional foods which have been introduced as a new concept $[4,5]$. This passionate history of fructans concerning their chemistry, biochemistry, enzymology and health benefits continues to arise interest of scientists who discover every day their potentials as foods and ingredients.

\footnotetext{
*Address correspondence to this author at the Department of Life Sciences, The Biotechnology Centre, The University of West Indies, Mona Camus, Kingston 7, Jamaica; Tel: +1 876970 6849; Fax: +1 876702 4203; E-mail: noureddine.benkeblia@uwimona.edu.jm
}

\section{CHEMISTRY OF FRUCTANS}

\section{Definition}

Fructans, poly-fructosylsucroses of varying molecular size build on a sucrose starter unit, are $1^{\mathrm{F}}(1-$ $\beta$-D-fructofuranosyl) $n$ sucrose oligomers where $n$ may vary. Fructans are considered as carbohydrates with varying degree of polymerization (DP) and consequently varying molecular weight [6]. They consist of one sucrose molecule to which other molecules of fructose have been added (Figure 1). The term of fructans is somewhat ambiguous since the number of fructose moieties added varies. However, major researchers agree that fructans have a polymerized chain of $n$ varying from 2 to 60 monosaccharides units. While, according to IUBIUPAC terminology, the dividing point between oligoand poly-fructooligosaccharides is 10 [7].

\section{Structure}

Because fructans nomenclature is not simple since their structures are variables, the nomenclatures for fructans proposed by Lewis [8], and, Waterhouse and Chatterton [9] are first used in literature. However from the purely chemical point of view, some controversies were raised in the scientific literature concerning this nomenclature. Yun [6] suggested that fructooligosaccharides are common names for only fructose oligomers that are mainly composed of 1-kestose [GF2 $=1$ kestotriose, $1^{\mathrm{F}}-\beta$-D-fructofuranosylsucrose], nystose $\left[\mathrm{GF} 3=1,1\right.$ kestotetraose, $1^{\mathrm{F}}$ (1- $\beta-\mathrm{D}$ - 


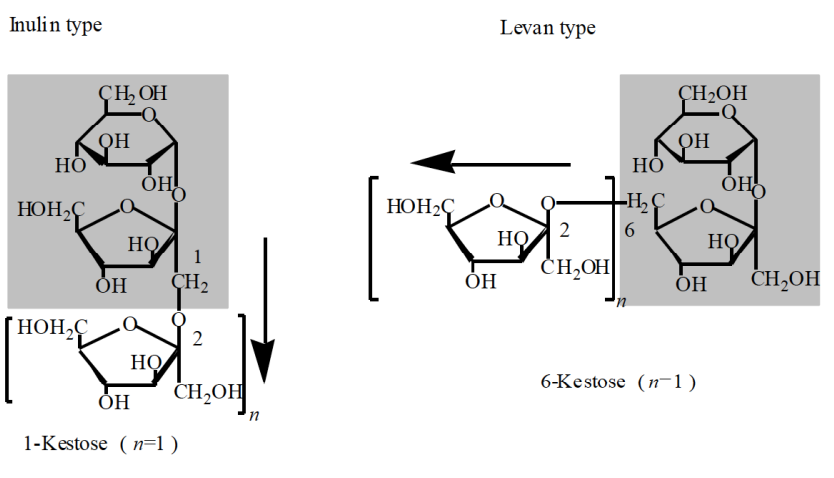

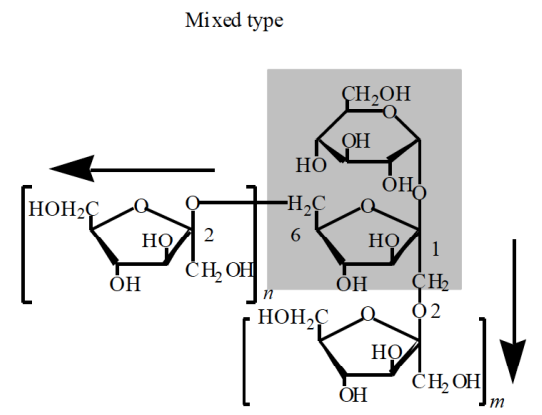

Bifurcose $(n=1, m=1)$
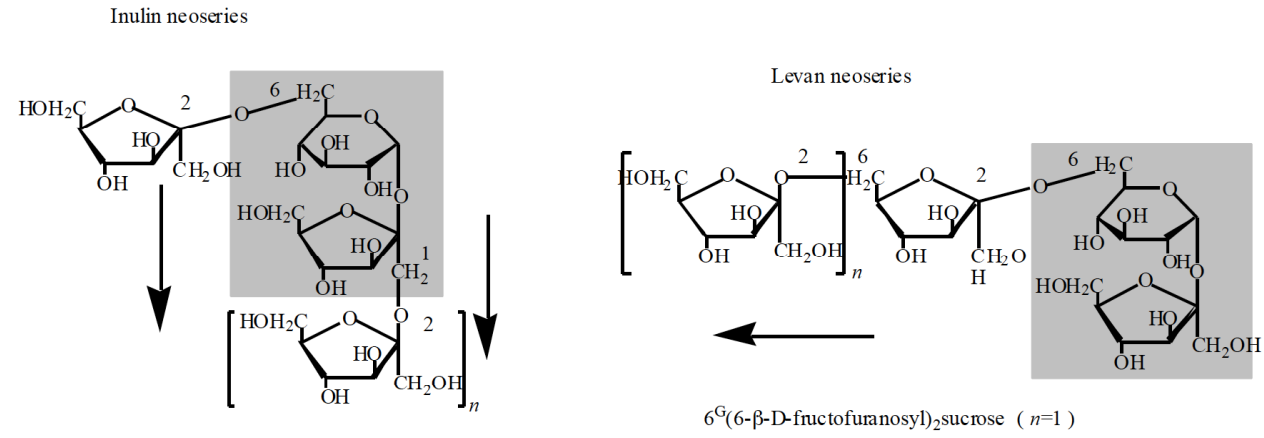

$1^{\mathrm{F}}, 6^{\mathrm{G}}$-Di- $\beta$-D-fruct ofuranos ylsucrose $(n=1)$

Figure 1: Molecular structures of the different types on fructooligosaccharides found in higher plants.

fructofuranosyl $)_{2}$ sucrose], and $1^{\mathrm{F}}$-fructofuranosyl nystose [GF4 $=1,1,1-$ kestopentaose $1^{F}$ (1- $\beta-D$ fructofuranosyl $)_{3}$ sucrose]. Therefore, the simple fructans are "inulin-type' which are linear and consist of $\beta(1-2)$-linked fructose residues and found in almost all fructan-containing plant (Figure 1).

Furthermore, the analytical studies carried out on their structures were characterized by a relative lack of data because chemical and/or enzymatic methods were used to assess and deduce high polymerized fructans on one hand, and techniques used for analyses did not allow the separation or identification of higher polymerized fructans on the other hand. Recently, new techniques for separating and determining the structural composition of the different short chain fructans have been developed. Shiomi [10] and Shiomi et al. [11,12] separated short FOS of onion bulbs using HPAEC-PAD technique, while Stahl et al. [13] used simultaneous MALDI-MS and HPAEC methods and obtained similar results.

\section{HEALTH BENEFITS OF FRUCTANS}

Generally, it is recommended to eat an average of $400 \mathrm{~g}$ of fruits and vegetables per day, and scientific advances linking diet and health have fostered unprecedented attention on the role of nutrition in health promotion and diseases prevention. This is fortunate as considerable evidences are indicating that adequate fruits and vegetables consumption has a role in preventing many chronic diseases, including heart diseases, stroke and several cancers [14-23]. Because of the great interest of consumers in diet food; and also fructans are not yet being well marketed widely throughout the world as food ingredients or additive, cultivated crops remain the main source of fructans such as banana, wheat, barley, asparagus, onion, garlic, chicory and Jerusalem artichoke [24-26]. Thus, fructans are presently produced industrially and used as food ingredients, while in Japan they are considered as food and are found in more than $\mathbf{5 0 0}$ food products including soft drinks, cookies, cereals and candies, resulting in significant daily consumption $[25,27]$.

Fructan-containing foods have been consumed because availability, low cost, and personal preference rather than for any specific effect on nutrition and health. In fact, the use of fructans in the human diet has increased since the initial commercial production of a specific oligofructan (Neosugar ${ }^{\circledR}$ ) in Japan in 1983. The benefits of adding fructans to the human diet has been first reported by the NSG (Neosugar Study Group) at a series of conferences held in Japan to highlight research with Neosugar® in 1982, 1983 and 
1984. The reports given have linked biochemicalnutritional-health changes in human resulting from eating Neosugar ${ }^{\circledR}$, and these results were confirmed later by Buddington et al. [28]. Although this history started with Neosugar $\AA$, it has become evident that many of the conclusions could be extended to other fructans [29].

Fructans also have numerous physiological actions [30], and Tomomatsu [27] enumerated the following health benefits attributed to oligosaccharides:

- Encourage proliferation of bifidobacteria and reduce detrimental bacteria

- Reduce toxic metabolites and detrimental enzymes

- $\quad$ Prevent pathogenic and autogenous diarrhea

- $\quad$ Prevent constipation

- $\quad$ Protect liver function

- $\quad$ Reduce serum cholesterol

- $\quad$ Reduce blood pressure

- Have an anticancer effect

- $\quad$ Produce nutrients

Thus, these physiological effects are the basis for associating fructans intake with reduced diseases and prevention.

\section{FRUCTANS AND MINERAL NUTRITION}

\section{Fructans and Calcium Nutrition}

Altough it was always thought that non-digestible carbohydrates cause an impairment in the small intestine absorption of minerals [31], studies conducted by van den Heuvel et al. [32,33] showed that the amount of calcium ions recovered in the ileostomate over a period of three days was significantly modified after supplementing the diet with $15 \mathrm{~g}$ per day of these fructans. Later, additional investigations were conducted on the effects of fructans and minerals (see review of Scholz-Ahrens et al. [34] and Scholz-Ahrens and Schrezenmeir [35]). However. Most of scientific evidences claiming that fructans enhance mineral absorption are mainly based on animal experiments [36-39], and only few on human ones [40-42]. Coudray et al. [38] studied the effects of different chain length and type of branched fructans on intestinal absorption and balance of calcium in rats and their results showed that all tested fructans studied seem to have similar activity by increasing absorption and/or balance of calcium. Lobo et al. [43] reported similar results when they supplemented diet with yacon flour and noted a significant positive balance of calcium leading to higher values of bone mineral retention. On human studies, Tahiri et al. [42] studied the effect of short-chain fructans and also noted these polymers may influence positively calcium absorption in the late postmenopausal phase. Additional experiments were conducted on the effects of oligofructose-enriched inulin absorption of calcium in postmenopausal women, and results were in agreement with those reported on animals regarding the positive effect of fructans on calcium absorption [44]. These data were confirmed by Jackman et al. [45] who noted that a daily intake of 50 mg per day of short chain fructans increased bone calcium retention in postmenopausal women.

Interestingly, the combination of oligofructose and highly polymerized-inulin (HP-inulin) showed synergetic effects on intestinal calcium absorption and balance. In thir studies conducted on humans, van Heuvel et al. [32] reported that $15 \mathrm{~g}$ of mixed oligofructose polymers per day stimulate fractional calcium absorption in male adolescents. Similar results also reported the increase of calcium absorption by combination of oligofructose + inulin in girl at or near menarche [41] and young adolescents as well [46].

On the other hand, other studies did not found consistent evidence between fructans intake and calcium absorption. Jamieson et al. [47] investigated the effect of long chain inulin on bone mineralization and density. In their conclusion, these authors reported that fructans did affect neither the bone mineral density (BMD) nor the whole body (WB) of the growing female rats. Experiment carried out on human by LópezHuertas et al. [48] also showed that milk with added fructooligosaccharides did not significantly increase calcium absorption.

Indeed, the mechanisms of calcium absorption are not fully understood yet, but it seems that different factors such as enhanced pools of soluble and ionized calcium, an increase in the absorptive surface in caecum, higher SCFAs (short chain fatty acids) concentrations, and by direct interaction with the intestinal tissue [49]. However, this retention and accumulation of calcium, as well as other minerals, in bone is enhanced only when the basic diet for the 
control group do not contain fructans and when the mineral demand is particularly high for example during growth [50].

\section{Fructans and Magnesium Nutrition}

Magnesium plays a central a role in many metabolic functions in humans, and all enzymatic reactions involving adenosine triphosphate have an absolute requirement for magnesium. Its metabolism appears to be very closely linked to calcium, potassium, and sodium, and its level is controlled by the kidneys and gastrointestinal tract [51,52]. van den Heuvel et al. $[32,33]$ indicated in their study that the amount magnesium ions recovering in the ileostomate over a period of three days was significantly modified by fructans supplemented diet. In their study, Coudray et al. [38] also reported that different fructans types seem to have similar activity by increasing absorption and/or balance of magnesium. Lobo et al. [43] reported similar observations and noted a positive balance of magnesium leading to higher values of bone mineral retention in rats resulting from a supplementation of the diet with yacon flour. Recent studies also confirmed these data by reporting similar effects when animals are fed, and a positive correlation was found between fructans consumption and magnesium absorption [53$55]$.

Experiments carried out on humans showed similar results to those observed on animals. Supplementation of diet with oligofructose-enriched inulin and a daily intake of short chain fructans increased bone magnesium retention in postmenopausal women $[44,45]$ and improved its absorption in adolescent girls with a low calcium intake [56].

\section{Fructans and Phosphorus Nutrition}

Alike calcium and magnesium, phosphorus is essential to human life, and during the process of bone hardening or aging, the $\mathrm{Ca}: \mathrm{P}$ ratio gradually increases from $1: 1$ to 1.67 . Hydroxyapatite is the predominant mineral of the bone with smaller quantities of intermediate calcium phosphates and some calcium carbonate. However, unlike calcium, phosphorus (and magnesium) requirements of adults are relatively low [57-59]. Comparatively, the number of studies on fructans and phosphorus absorption is much less than that conducted on calcium and magnesium. In his study, Scholz-Ahrens et al. [37] noted that oligofructans affected significantly magnesium when dietary calcium was high, and similar observation was reported by
Pérez-Conesa et al. [60] showing an increase in phosphorus bioavailability in rats fed with prebiotics supplemented diet.

\section{Fructans and other Minerals Nutrition}

The effects of fructans on the absorption of minerals is quite well documented in animals, however, results of studies on humans are questionable. Although fructans and calcium and magnesium absorption has been the most studied, the ability of fructans to enhance absorption of other minerals, such as iron, zinc, and copper, has been also studied, but not all these studies have shown increased mineral absorption in animals when fed by non-digestible oligosaccharides.

For living organisms, iron ( $\mathrm{Fe})$ is essential and involved in numerous metabolic processes such as oxygen transport, deoxyribonucleic acid (DNA) synthesis, and electron transport. Nevertheless, its level requires a controlled regulation because excessive amounts might cause tissue damages [61]. In controversial studies, iron status in rats was not affected by inulin-type fructans (ITF) supplementation [62], while later the same authors observed that ITF increased iron bioavailability and its level in liver [63]. Human experiment showed no evidence between fructans intake and iron absorption, and even showing prebiotic effects, inulin did not improve iron absorption in women having low iron status [64].

Zinc is another essential mineral although at low doses, and its deficiency is now known to be an important malnutrition problem. In nutrition, zinc bioavailability plays a crucial role in its absorption, and phytates are the main known inhibitor of zinc, decreasing its availability, thus prevailing its high deficiency in large cereal proteins consumers $[65,66]$.

As for zinc, little is known on the biochemical defects, physiological dysfunction, and clinical manifestations of copper and its metabolism, and studies to determine human copper status are limited. However, copper-dependent functions can be affected by intracellular distribution as well as total-body depletion of this mineral nutrient, and concerted effort to improve status assessment through the use of functional indices are becoming a high priority [67-69]

Studies investigating how fructans can affect zinc and copper availability and absorption are very scarce. Coudray et al. [70] investigated the effect of inulin 
intake on zinc and copper absorption, and any correlation with the age of animals and the absorption of these two minerals. Their results showed that dietary inulin intake affected significantly intestinal absorption of zinc and copper in rats, and this absorption was much higher in older than younger animals. Similar and positive effects of fructoligosaccharides on zinc and copper absorption were reported by Lopez et al. [71]. In contrary, Vaz et al. [53] did not find any change in zinc status of iron-deficient rats fed with inulin-type fructans supplemented diet, while copper was negatively affected.

\section{COMMENTARIES AND CONCLUSION}

From the literature and beside the progress done on understanding the roles of fructans in mineral nutrition, the results reported by these investigation are sometimes consistent and sometimes not. In fact, what makes the issue complex is the understanding of the mechanisms behind minerals availability and absorption. On these mechanisms, different hypotheses have been suggested and some of them are making a good consensus. The hypotheses most frequently proposed to explain the enhancing effects of fructans on mineral absorption are: (i) the osmotic effect, (ii) acidification of the colonic content due to fermentation and production of short-chain carboxylic acids (SCFAs), (iii) formation of calcium and magnesium salts of these acids, and (iv) hypertrophy of the colon wall $[72,73]$. However, according to Ohta et al. [36] and Raschka and Daniel [49], other and different mechanisms may be involved in the increased absorption of calcium and magnesium, the former being absorbed mostly in the cecum and the later mostly in the colon. Other issues are the discrepancies between animal and human studies, and most of these results have been observed in animals, and few were conducted on human. Even though the beneficial effects of fructans on mineral absorption (and other metabolic functions as well) do not suffer from any ambiguity, still further work needs to be done and the mechanisms are yet to be determined in order to clarify how and what regulate fructans and minerals interactions, including their promoters and inhibitors. Indeed, numerous and complex reactions occur in the intestine and might interfere with the mechanisms of fructans-minerals absorption. In the future and to further clarify the roles of fructans in mineral nutrition, two main approaches could be adopted. Firstly, we need to understand the mechanisms of how fructans increase the absorption of some minerals and why not most of the essential ones. Secondly, we need to extend findings in animal models to human, with a particular emphasis on young and elderly persons.

\section{REFERENCES}

[1] Meier H, Reid JS. Reserve polysaccharides other than starch in higher plants. In: Loewus FA, Tanner W, editors. Encyclopaedia of plant physiology. New Series. Berlin: Springer Verlag 1982; p. 418-71. http://dx.doi.org/10.1007/978-3-642-68275-9_11

[2] Pontis HG, Del Campillo E. Fructan. In: Dey PM, Dixon RA, editors. Biochemistry of storage carbohydrates in green plants. London: Academic Press 1985; p. 205-27.

[3] Pollock CJ, Cairns AJ. Fructan metabolism in grasses and cereals. Annu Rev Plant Physiol Plant Mol Biol 1991; 42: 77101.

http://dx.doi.org/10.1146/annurev.pp.42.060191.000453

[4] Duggan C, Gannon J, Walker WA. Protective nutrients and functional foods for the gastrointestinal tracts. Am J Clin Nutr 2002; 75: 789-808.

[5] Roberfroid MB. Functional foods: concepts and application to inulin and oligofructose. Br J Nutr 2002; 87 (Suppl. 2): S13943.

http://dx.doi.org/10.1079/BJN/2002529

[6] Yun JW. Fructooligosaccharides - occurrence, preparation, and application. Enz Microbial Technol 1996; 19: 107-17. http://dx.doi.org/10.1016/0141-0229(95)00188-3

[7] IUB-IUPAC Joint Commission on Biochemical Nomenclature (JCBN). Abbreviated terminology of oligosaccharide chains. Recommendations 1980. J Biol Chem 1982; 257: 3347-51.

[8] Lewis DH. Nomenclature and diagrammatic representation of oligomeric fructans- a paper for discussion. New Phytol 1993; 124: 583-94.

http://dx.doi.org/10.1111/j.1469-8137.1993.tb03848.x

[9] Waterhouse AL, Chatterton NJ. Glossary of fructan terms. In: Suzuki M, Chatterton NJ, editors. Science and technology of fructans. Boca Raton (FL): CRC Press 1993; p. 1-7.

[10] Shiomi N. Structure of fructo-polysaccharide (asparagosin) from roots of asparagus (Asparagus officinalis L.). New Phytol 1993; 123: 263-70. http://dx.doi.org/10.1111/j.1469-8137.1993.tb03734.x

[11] Shiomi N, Onodera S, Chatterton NJ, Harrison PA. Separation of fructooligosaccharide isomers by anionexchange chromatography. Agric Biol Chem 1991; 55: 14278.

[12] Shiomi N, Onodera S, Sakai H. Fructo-oligosaccharide content and fructosyltransferase activity during growth of onion bulbs. New Phytol 1997; 136: 105-13. http://dx.doi.org/10.1111/j.1469-8137.1997.tb04736.x

[13] Stahl B, Linos A, Karas M, Hillenkamp F, Steup M. Analysis of fructans from higher plants by matrix-assisted laser desorption/ionization mass spectrometry. Anal Biochem 1997; 246: 195-204. http://dx.doi.org/10.1006/abio.1997.2011

[14] WCRF-AICR (World Cancer Research Fund-American Institute of Cancer Research). Food, nutrition and the prevention of cancer: a global perspective. 2007. [Cited 2016 August 5]. Available from: http://www.aicr.org/research/ research_science_expert_report.html

[15] Ness AR, Powles JW. Fruits and vegetables, and cardiovascular disease: A review. Int J Epidemiol 1997; 26 1-13.

http://dx.doi.org/10.1093/ije/26.1.1

[16] Joshipura KJ, Ascherio A, Mansun J, et al. Fruit and vegetable intake in relation to risk of ischaemic stroke. $\mathrm{J} \mathrm{Am}$ Med Assoc 1999; 282: 1233-9.

http://dx.doi.org/10.1001/jama.282.13.1233 
[17] Johnsen SP, Overvad K, Stripp C, Tjonneland A, Husted SE, Sorensen HT. Intake of fruit and vegetable and the risk of ischaemic stroke in a cohort of Danish men and woman. Am J Clin Nutr 2003; 78: 57-64.

[18] Appel LJ, Moore TJ, Obarzanek E, et al. A clinical trial of the effects of dietary patterns on blood pressure. New Engl J Med 1997; 336: 1117-24.

http://dx.doi.org/10.1056/NEJM199704173361601

[19] Block J, Patterson B, Subar A. fruits, vegetables and cancer prevention: a review of the epidemiological evidence. Nutr Cancer 1992; 18: 1-29. http://dx.doi.org/10.1080/01635589209514201

[20] Hertog MG, Bueno de Mesquita GB, Fehily A, Sweetnam PM, Elwood PC, Kroumhout D. Fruit and vegetable consumption and cancer mortality in the $C$ aerphilly study. Epidemiol Biomarkers Prev 1996; 5: 673-7.

[21] Olsen M, Gudmand-heyer E. Efficacy, safety, and tolerability of fructooligosaccharides in the treatment of irritable bowel syndrome. Am J Clin Nutr 2000; 72: 1570-5.

[22] Flamm G, Glinsman W, Kritchevsky D, Prosky L, Roberfroid $M$. Inulin and oligofructose as dietary fiber: A review of the evidence. Crit Rev Food Sci Nutr 2001; 45: 353-62. http://dx.doi.org/10.1080/20014091091841

[23] Cherbut $\mathrm{C}$. Inulin and oligofructose in the dietary fiber concept. Br J Nutr 2002; 87 (Suppl. 2): S159-62. http://dx.doi.org/10.1079/BJN2002532

[24] Mitsuoka T, Hidaka H, Eida T. Effects of fructooligosaccharides on intestinal microflora. Nahrung 1987; 31 : 427-36.

http://dx.doi.org/10.1002/food.19870310528

[25] Spiegel JE, Rose R, Karabell P, Franks VH, Schmitt DF. Safety and benefits of fructooligosaccharides as food ingredients. Food Technol 1994; 1: 85-9.

[26] Tashiro $Y$, Eida T, Hidaka H. Distribution and quantification of fructooligosaccharides in food materials. Sci Rep Meiji Seiki Kaisha 1992; 31: 35-40.

[27] Tomomatsu $\mathrm{H}$. Health effects of oligosaccharides. Food Technol 1994; 10: 61-5.

[28] Buddington RK, Williams $\mathrm{CH}$, Chen SC, Witherly SA. Dietary supplement of neosugar alters fecal flora and decreases activities of some reductive enzymes in human subjects. Am J Clin Nutr 1996; 63: 709-16.

[29] Farnworth ER. Fructans in human and animal diet. In: Suzuki $\mathrm{M}$, Chatterton NJ, editors. Science and technology of fructans. Boca Raton (FL): CRC Press, 1993; p. 257- 72.

[30] Scheppach W, Luehrs H, Menzel T. Beneficial health effects of low-digestible carbohydrate consumption. Br J Nutr 2001; 85 (Suppl. 1): S23-30.

http://dx.doi.org/10.1079/BJN2000259

[31] Ellegård L, Andersson $\mathrm{H}$, Bosaeus I. Inulin and oligofructose do not influence the absorption of cholesterol, or the excretion of cholesterol, $\mathrm{Ca}, \mathrm{Mg}, \mathrm{Zn}$, Fe, or bile acids but increases energy excretion in ilestomy subjected. Eur $\mathrm{J}$ Clin Nutr 1997; 41: 1-5. http://dx.doi.org/10.1038/sj.ejcn. 1600320

[32] van den Heuvel EGMH, Schaafsma G, Muys T, van Dokkun W. Nondigestible oligosaccharides do not interfere with calcium and nonheme-iron absorption in young, healthy men. Am J Clin Nutr 1998; 67: 445-51.

[33] van den Heuvel EGMH, Muys T, van Dokkun W Schaafsma G. oligofructose stimulates calcium absorption in adolescents. Am J Clin Nutr 1999; 69: 544-8.

[34] Scholz-Ahrens K, Schaafsma G, van den Heuvel EGMH, Schrezenmeir J. Effects of prebiotics on mineral absorption. Am J Clin Nutr 2001; 73 (Suppl.): 459S-64.

[35] Scholz-Ahrens K, Schrezenmeir J. Inulin, oligofructose and mineral metabolism - experimental data and mechanism. $\mathrm{Br}$ J Nutr 87 (Suppl. 2): S179-86.
Ohta A, Ohtsuki M, Baba S, Takizawa T, Adachi T, Kimura S. Effects of fructooligosaccharides on the absorption of iron, calcium and magnesium in iron- deficiency anemic rats. $J$ Nutr Sci Vitaminol 1995; 41: 281-91.

http://dx.doi.org/10.3177/jnsv.41.281

[37] Scholz-Ahrens K, Schrezenmeir J. Effect of oligofructose on dietary calcium on repeated calcium and phosphorus balances, bone mineralization and tubular structure in ovariectomized rats. Br J Nutr 2002; 88: 365-77. http://dx.doi.org/10.1079/BJN2002661

[38] Coudray C, Bellanger J, Castiglia-Delavaud C, Rémésy C Vermorel M, Rayssiguier $\mathrm{Y}$. Effects of inulin-type fructans of different chain length and type of branching on intestinal absorption and balance of calcium and magnesium in rats. Eur J Nutr 2003; 42: 91-8. http://dx.doi.org/10.1007/s00394-003-0390-x

[39] Flickinger EA, Van Loo J, Fahey C. Nutritional responses to the presence of inulin and oligofructose in the diets of domesticated animals: A review. Crit Rev Food Sci Nutr 2003; 43: 19-60.

http://dx.doi.org/10.1080/10408690390826446

[40] Coudray C, Bellanger J, Castiglia-Delavaud C, Rémésy C, Vermorel M, Rayssiguier Y. Effect of soluble or partly soluble dietary fibers supplementation on absorption and balance of magnesium, iron and zinc in healthy young men. Eur $\mathrm{J}$ Clin Nutr 1997; 51: 375-80. http://dx.doi.org/10.1038/sj.ejcn.1600417

[41] Griffin IJ, Davila PM, Abrams, SA. Non-digestible oligosaccharides and calcium absorption in girls with adequate calcium intakes. Br J Nutr 2002; 879 (Suppl. 2): S187-91.

[42] Tahiri M, Tressol JC, Arnaud J, et al. Effect of short-chain fructooligosaccharides on intestinal calcium absorption and calcium status in postmenopausal women: a stable-isotope study. 42 Am J Clin Nutr 2003; 77: 449-57.

[43] Lobo AR, ColliC, Alvares EP, Filisetti TMCC. Effects of fructans-containing yacon (Smallanthus sonchifolius Poepp \& Endl.) flour on caecum mucosal morphometry, calcium and magnesium balance, and bone calcium retention in growing rats. Br J Nutr 2007; 97: 776-85. http://dx.doi.org/10.1017/S0007114507336805

[44] Holloway L, Moynihan S, Abrams SA, Kent K, Hsu AR, Friedlander AL. 2007. Effects of oligofructose-enriched inulin on intestinal absorption of calcium and magnesium and bone turnover markers in postmenopausal women. Br J Nutr 2007; 97: 365-72.

http://dx.doi.org/10.1017/S000711450733674X

[45] Jakeman Sa, Henry CN, Martin BR, et al. Soluble corn fiber increases bone calcium retention in postmenopausal women in a dose-dependent manner: a randomized crossover trial. Am J Cllin Nutr 2016; 104: 837-43. http://dx.doi.org/10.3945/ajcn.116.132761

[46] Abrams SA, Griffin IJ, Hawthorne KM, et al. A combination of prebiotic short- and long-chain inulin-type fructans enhances calcium absorption and bone mineralization in young adolescents. Am J Clin Nutr 2005; 82: 471-6.

[47] Jamieson JA, Ryza NA, Taylora CG, Weiler HA. Dietary longchain inulin reduces abdominal fat but has no effect on bone density in growing female rats. Br J Nutr 2008; 100: 451-9. http://dx.doi.org/10.1017/S0007114508894378

[48] López-Huertas E, Teucher B, Boza JJ, et al. Absorption of calcium from milks enriched with fructo-oligosaccharides, caseinophosphopeptides, tricalcium phosphate, and milk solids. Am J Clin Nutr 2006; 83: 310-6.

[49] Raschka, L, Daniel H. Mechanisms underlying the effects of inulin-type fructans on calcium absorption in the large intestine of rats. Bone 2005; 37: 728-35. http://dx.doi.org/10.1016/..bone.2005.05.015 
[50] Raschka, L, Daniel H. Diet composition and age determine the effects of inulin-type fructans on intestinal calcium absorption in rat. European J Nutr 2005; 44: 360-4. http://dx.doi.org/10.1007/s00394-004-0535-6

[51] Reinhart RA. Magnesium metabolism: A review with special reference to the relationship between intracellular content and serum levels. Arch Intern Med 1988; 148: 2415-20. http://dx.doi.org/10.1001/archinte.1988.00380110065013

[52] Vormann K. Magnesium: nutrition and metabolism. Mol Asp Med 2013; 24: 27-37. http://dx.doi.org/10.1016/S0098-2997(02)00089-4

[53] Vaz RTC, Lobo AR, Cocato ML, Coll C. Effects of inulin-type fructans consumption on mineral intestinal absorption and balance in rats fed control andiron-deficient diets. Alim Nutr Araraquara 2010; 21: 7-13.

[54] García-Vieyra MI, Del Real A, López MG. Agave fructans: Their effect on mineral absorption and bone mineral content. J Med Food 2014; 17: 1247-55. http://dx.doi.org/10.1089/jmf.2013.0137

[55] Legette LCL, Lee WH, Martin BR, Story JA, Campbell JK, Weaver CM. Prebiotics enhance magnesium absorption and inulin-based fibers exert chronic effects on calcium utilization in a postmenopausal rodent model. J Food Sci 2012; 77: 8894.

http://dx.doi.org/10.1111/j.1750-3841.2011.02612.x

[56] van den Heuvel EGHM, Muijs T, Brouns F, Hendriks HFJ. Short-chain fructo-oligosaccharides improve magnesium absorption in adolescent girls with a low calcium intake. Nutr Res 2009; 29: 229-37. http://dx.doi.org/10.1016/j.nutres.2009.03.005

[57] Cashman KD, Flynn A. Optimal nutrition: calcium, magnesium and phosphorus. Proc Nutr Soc 1999; 58: 47787. http://dx.doi.org/10.1017/S0029665199000622

[58] Calvo MS. Dietary phosphorus, calcium metabolism and bone. J Nutr 1993; 123: 1627-33.

[59] Driessens FMC, Verbeeck RMH, Eds. Biominerals. Boca Raton (FL): CRC Press 1990.

[60] Pérez-Conesa D, López G, Abellán P, Ros G. Bioavailability of calcium, magnesium and phosphorus in rats fed probiotic, prebiotic and synbiotic powder follow-up infant formulas and their effect on physiological and nutritional parameters. J Sci Food Agri 2006; 86: 2327-36. http://dx.doi.org/10.1002/jsfa.2618

[61] Abbaspour N, Hurrell R, and Kelishadi R. Review on iron and its importance for human health. J Res Med Sci 2014; 19: 164-74.
[62]

Lobo AR, Cocato ML, Jorgetti V, de Sác LRM, Nakano EY, Colli C. Changes in bone mass, biomechanical properties, and microarchitecture of calcium- and iron-deficient rats fed diets supplemented with inulin-type fructans. Nutr Res 2009; 29: 873-81. http://dx.doi.org/10.1016/j.nutres.2009.10.012

[63] Lobo AR, Cocato ML, Borelli $P$, et al. Iron bioavailability from ferric pyrophosphate in rats fed with fructan-containing yacon (Smallanthus sonchifolius) flour. Food Chem 2011; 126: 88591. http://dx.doi.org/10.1016/j.foodchem.2010.11.067

[64] Petry N, Egli I, Chassard C, Lacroix C, Hurrell R. Inulin modifies the bifidobacteria population, fecal lactate concentration, and fecal $\mathrm{pH}$ but does not influence iron absorption in women with low iron status. Am J Clin Nutr 2012; 96: 325-31. http://dx.doi.org/10.3945/ajcn.112.035717

[65] Prasad AS. Discovery and importance of zinc in human nutrition. Fed Proc 1984; 43: 2829-34.

[66] Roohani N, Hurrell R, Kelishadi R, Schulin R. Zinc and its importance for human health: An integrative review. J Res Med Sci 2013; 18: 144-57.

[67] Solomons NW. Biochemical, metabolic, and clinical role of copper in human nutrition. J Am Coll Nutr 1985; 4: 83-105. http://dx.doi.org/10.1080/07315724.1985.10720069

[68] Williams DM. Copper deficiency in humans. Semin Hematol 1983; 20: 118-28.

[69] Wachnik A. The physiological role of copper and the problems of copper nutritional deficiency. Food-Nahrung 1988; 32: 755-65. http://dx.doi.org/10.1002/food.19880320811

[70] Coudray C, Feillet-Coudray C, Gueux E, Mazur A, Rayssiguier $Y$. Dietary inulin intake and age can affect intestinal absorption of zinc and copper in rats. J Nutr 2006; 136: 117-22.

[71] Lopez HW, Coudray C, Levrat-Verny MA, Feillet-Coudray C, Demigné $C$, Rémésy $C$. Fructooligosaccharides enhance mineral apparent absorption and counteract the deleterious effects of phytic acid on mineral homeostasis in rats. J Nutr Biochem 2000; 11: 500-8. http://dx.doi.org/10.1016/S0955-2863(00)00109-1

[72] Younes $\mathrm{H}$, Demigné $\mathrm{C}$, Rémésy $\mathrm{C}$. Acidic fermentation in the caecum increases absorption of calcium and magnesium in the large intestine of the rat. Br J Nutr 1996; 75: 301-14. http://dx.doi.org/10.1079/BJN19960132

[73] Cashman K. Pebiotics and $\mathrm{Ca}$ bioavailability. Curr Issues Intest Microbiol 2003; 4: 21-32. 